\title{
Bacterial biofilm formation on the bladder epithelium of spinal cord injured patients. II. Toxic outcome on cell viability
}

\author{
G Reid PhD, ${ }^{1,2}$ Y S Kang, Student, ${ }^{1}$ M Lacerte MD ${ }^{3}$ C Tieszer BSc, ${ }^{1} \mathrm{~K}$ C Hayes $\mathrm{PhD}^{3}$ \\ ${ }^{I}$ Department of Microbiology and Immunology, Office of Research Services, SLB 328, \\ University of Western Ontario, London, Ontario, Canada, N6A 5B8; ${ }^{2}$ Division of \\ Urology, University of Toronto; ${ }^{3}$ Department of Physical Medicine and Rehabilitation, \\ Parkwood Hospital and University of Western Ontario London, Ontario, Canada.
}

As a follow up to our first study of 10 spinal cord injured patients, a further 8 patients were investigated over 2 months for biofilm formation on their bladder epithelial cells and for evidence that these uropathogens damage the host bladder. All the patients were found to be colonized with uropathogens, regardless of whether or not they were receiving antibiotics. Using vital staining, it was discovered that there was a significant reduction $(33 \%)$ in bladder cell viability in the presence of bacterial biofilms compared to controls. This was not associated with cell turnover rates. In vitro tests showed a similar reduction in cell viability when uropathogens were incubated with bladder cells. In addition, white cell counts were significantly elevated in the patients' urine, indicative of an infectious and/or inflamed state. There was no difference between symptomatic and asymptomatic patients in their mean bacterial adhesion counts. Patients were just as likely to be symptomatic as asymptomatic when on antibiotics. In summary, the presence of virulent organisms in the bladder does adversely affect the host, even when the patient has insignificant signs and symptoms of infection, thereby raising concerns over the decision not to treat the patient. Unless specific antibiotics are used which eradicate adherent biofilms from the bladder, the treatment of symptomatic patients will only impact upon the signs and symptoms in some patients, and not alter their susceptibility to reinfection.

Keywords: bacterial biofilms; toxicity for bladder epithelium; spinal cord injured patients.

\section{Introduction}

The recent finding of adherent bacterial biofilms on the bladder cells of spinal cord injured (SCI) patients raises questions as to how well we understand and manage bacteriuria in these patients? ${ }^{1}$ A consensus statement from the National Institute on Disability and Rehabilitation Research ${ }^{2}$ suggested that symptomatic urinary tract infection (UTI) should be treated for 7-14 days without culture results, and that asymptomatic bacteriuria need not be treated. The scientific or clinical basis for these conclusions is not well established. As has been stated previously, the management of UTI in SCI patients should have a scientific basis. ${ }^{3}$

Having already shown the existence of uropathogens in large numbers in biofilms on bladder cells of SCI patients, it was our hypothesis that these organisms would be damaging the host's bladder, even although the patient may present with few signs and relatively mild symptoms. The present study was undertaken to investigate this, using a group of 8 patients who had not been part of the previous study. To substantiate previous findings and to provide a baseline for this investigation, we followed the same protocol as before. However, particular attention was paid to bladder cell viability and the presence of white blood cells as indicators of damage to the uroepithelium. In vitro experiments were also carried out to determine the effect on cell viability of incubating uropathogens with bladder cells. 


\section{Patients and methods}

Eight SCI patients who were undergoing a hospital rehabilitation program provided written consent to participate in the study, after approval of the protocol by the Parkwood Hospital, London, Ontario and the University of Western Ontario Health Review Boards. The clinical status, sex and age of the patients are shown in Table I. The patients were using intermittent catheterization for bladder management, and they provided urine samples via this catheter insertion over weekly intervals for 8 weeks. During this time, they were monitored for signs and symptoms of UTI, namely, spasticity, fever, cloudy urine, and foul odour. Co-trimoxazole, in particular, was given in theory to prevent signs and symptoms from arising. Antibiotics were administered if these signs and symptoms were present and if the physician was concerned about bacterial ascension to upper tract infection. The planktonic organisms isolated from the bladder urine were sensitive to the antibiotics prescribed.

A similar experimental protocol was followed to that in the previous study for detection of biofilms, ${ }^{1}$ with the additional steps of determining the white blood cell count in unspun urine and the percentage cell viability of the 50 trypan blue $(0.4 \%)$ stained sediment epithelial cells within 4 hours of collection. An additional double staining technique using trypan blue $(0.4 \%)$ with safranine $(1 \%)$ was employed to identify bacteria adherent to live and dead cells. Transitional epithelial cells only were evaluated and on occasion some samples were plated to confirm viability of adherent bacteria. Four volunteers without spinal cord injury were able to provide control samples: they were aged 22 and 59 (male), 21 (female) and 65 (a healthy old woman who was using intermittent catheterization for an atonic neurogenic bladder).

An in vitro experiment was also undertaken, whereby $1 \times 10^{5}$ bladder sediment cells from a healthy female were incubated at $37^{\circ} \mathrm{C}$ for 1 hour in urine with $1 \times 10^{8}$ uropathogenic strains $E$. coli $\mathrm{Hu} 734$, and SCI patient isolates Klebsiella pneumoniae, Pseudomonas aeruginosa and Enterococcus faecalis. The cells were washed in phosphate buffered saline, stained with trypan blue and assessed for percentage viability.

\section{Results}

The results are summarized in Table I and show that during the weeks of study every patient developed adherent bacterial biofilms. These comprised E. coli (9 times), Enterococcus sp. (7), Klebsiella pneumoniae (2), Pseudomonas aeruginosa (2), mixed culture (1) and unidentified Gram negative rods (2) and Gram positive cocci (1). Of 53 uroepithelial cell samples and urines that were able to be tested, the urine was negative when adherent biofilms were present in $31(58 \%)$ cases. There was no difference between the bacterial numbers adherent to live (mean $25 \pm$ standard deviation 13 bacteria per cell) and dead (31 \pm 17 per cell) epithelial cells, nor the numbers of bacteria adherent to cells when patients were given antibiotics ( $27 \pm 13$ bacteria per cell) compared to those left untreated $(29 \pm 15$ per cell). There was no difference between the number of bacteria adherent to cells from patients who were symptomatic $(30 \pm 14$ per cell) and asymptomatic (26 \pm 14 per cell). During 17 patient weeks, patients receiving antibiotics were asymptomatic, while during 16 patient weeks they were still symptomatic. When no antibiotics were given, there were 9 patient weeks when patients were asymptomatic and 16 when they were symptomatic.

The viability of the bladder cells was quite varied, but overall there was a significant $(33 \%, p<0.001)$ drop in viability when compared to controls $(53 \pm 24 \%$ vs $79 \pm$ $13 \%)$. This was not due to cell turnover, as every urine sample was quantitated for cells per $\mathrm{ml}$ to exclude this possibility. There was no direct correlation between loss of cell viability and the mean bacterial count per cell (Fig 1) ( $r=-0.01)$. Low and high adhesion counts were found when there was $50 \%$ cell death. The administration of antibiotics was associated with a slight loss in cell viability, but this was not statistically significant $(62 \pm 20$ to $49 \pm 23$ bacteria per cell). The presence of symptoms was not associated with bladder cell viability $(53 \pm 22 \%$ viability for symptomatic vs 
Table I Clinical status, sex and age of patients

\begin{tabular}{|c|c|c|c|c|c|c|c|c|c|c|}
\hline \multirow[t]{2}{*}{ Patient } & \multirow{2}{*}{$\begin{array}{c}\text { Sex } \\
\text { (Age) }\end{array}$} & & \multicolumn{8}{|c|}{ Week of study } \\
\hline & & & 1 & 2 & 3 & 4 & 5 & 6 & 7 & 8 \\
\hline \multirow[t]{4}{*}{1} & $\mathrm{~F}$ & A Bacteria per cell & 18 & 11 & 51 & 13 & 38 & 27 & NA & DC \\
\hline & (33) & B Antibiotics & CT & CT & CT & CT & CT & 0 & $\mathrm{NF}$ & \\
\hline & & C Urinary infection & $\mathrm{N}$ & $\mathrm{N}$ & $\mathrm{Y}$ & $\mathrm{N}$ & $\mathrm{N}$ & $\mathrm{Y}$ & $\mathrm{Y}$ & \\
\hline & & D Cell viability & 5 & 62 & 45 & 40 & 54 & 80 & NA & \\
\hline \multirow[t]{4}{*}{2} & $\mathrm{M}$ & A Bacteria per cell & 8 & 34 & 18 & 35 & 44 & NA & NA & 39 \\
\hline & (21) & B Antibiotics & CT & CT & CT & CT & CT & CT & CT & CT \\
\hline & & C Urinary infection & $\mathrm{N}$ & $\mathrm{N}$ & $\mathrm{N}$ & $\mathrm{N}$ & $\mathrm{N}$ & $\mathrm{N}$ & $\mathrm{N}$ & $\mathrm{N}$ \\
\hline & & D Cell viability & 100 & 47 & 9 & 79 & 42 & 82 & NA & 57 \\
\hline \multirow[t]{4}{*}{3} & $\mathbf{M}$ & A Bacteria per cell & 41 & 36 & 28 & 23 & 17 & 17 & NA & 13 \\
\hline & (64) & B Antibiotics & 0 & 0 & 0 & $\mathrm{AX}$ & 0 & 0 & 0 & 0 \\
\hline & & C Urinary infection & $\mathrm{Y}$ & $\mathrm{Y}$ & $\mathrm{Y}$ & Y & $\mathrm{N}$ & $\mathrm{Y}$ & $\mathrm{Y}$ & $\mathrm{Y}$ \\
\hline & & D Cell viability & 67 & 68 & 26 & 34 & 46 & 85 & NA & 71 \\
\hline \multirow[t]{4}{*}{4} & $\mathrm{~F}$ & A Bacteria per cell & 38 & 32 & 37 & 48 & NA & 38 & 54 & 20 \\
\hline & (35) & B Antibiotics & AP & CL & $\mathrm{CF}$ & $\mathrm{CF}$ & 0 & 0 & 0 & $\mathrm{KF}$ \\
\hline & & C Urinary infection & $\mathrm{Y}$ & $\mathrm{Y}$ & $\mathrm{Y}$ & $\mathrm{Y}$ & $\mathrm{N}$ & $\mathrm{N}$ & $\mathrm{N}$ & $\mathrm{N}$ \\
\hline & & D Cell viability & 11 & 79 & 11 & 42 & NA & 71 & 87 & 63 \\
\hline \multirow[t]{4}{*}{5} & $\mathbf{M}$ & A Bacteria per cell & 21 & NA & 21 & 17 & 8 & 11 & 27 & 11 \\
\hline & (20) & B Antibiotics & 0 & 0 & 0 & 0 & AP & CT & CT & $\mathrm{CT}$ \\
\hline & & C Urinary infection & $\mathrm{Y}$ & $\mathrm{Y}$ & $\mathrm{Y}$ & $\mathrm{N}$ & $\mathrm{N}$ & $\mathrm{Y}$ & $\mathrm{Y}$ & $\mathrm{Y}$ \\
\hline & & D Cell viability & 85 & NA & 90 & 81 & 31 & 67 & 57 & 60 \\
\hline \multirow[t]{4}{*}{6} & M & A Bacteria per cell & NA & 47 & 15 & 14 & 33 & 46 & 8 & 8 \\
\hline & (33) & B Antibiotics & 0 & 0 & CT & CT & CT & CT & $\mathrm{CT}$ & NA \\
\hline & & C Urinary infection & $\mathrm{Y}$ & $\mathrm{N}$ & $\mathrm{Y}$ & $\mathrm{Y}$ & $\mathrm{Y}$ & $\mathrm{Y}$ & $\mathrm{N}$ & NA \\
\hline & & D Cell viability & NA & 76 & 70 & 41 & 53 & 57 & 50 & 45 \\
\hline \multirow[t]{4}{*}{7} & M & A Bacteria per cell & 41 & 19 & 33 & 45 & 40 & NA & 10 & NA \\
\hline & (36) & B Antibiotics & $\mathrm{CX}$ & GT & 0 & 0 & CT & 0 & 0 & 0 \\
\hline & & C Urinary infection & $\mathrm{N}$ & $\mathrm{Y}$ & $\mathrm{Y}$ & $\mathrm{Y}$ & $\mathrm{Y}$ & $\mathrm{Y}$ & 0 & 0 \\
\hline & & D Cell viability & 36 & 14 & 36 & 49 & 47 & NA & 54 & NA \\
\hline \multirow[t]{4}{*}{8} & M & A Bacteria per cell & 19 & NA & 65 & 25 & 15 & 13 & 25 & 54 \\
\hline & $(62)$ & B Antibiotics & $\mathrm{KF}$ & 0 & 0 & 0 & 0 & 0 & NA & NA \\
\hline & & C Urinary infection & $\mathrm{N}$ & $\mathrm{N}$ & $\mathrm{Y}$ & $\mathrm{N}$ & $\mathrm{Y}$ & $\mathrm{N}$ & NA & NA \\
\hline & & D Cell viability & 64 & NA & 40 & 48 & 54 & 33 & 51 & 62 \\
\hline
\end{tabular}

Patients 1, 2, 5, 6, 7 were quadraplegic. Patients $3,4,8$ were paraplegic

$\mathrm{A}=$ Mean number of adherent bacteria per bladder cell

$\mathrm{B}=$ Antibiotics administered

$\mathrm{C}=$ Presence of signs and symptoms of urinary tract infection

$\mathrm{D}=$ Percentage of bladder cells that were viable

$\mathrm{CT}=$ Co-trimoxazole double strength $\mathrm{QD}$

MF $=$ Norfloxacin $400 \mathrm{mg}$ BD for 7 days

$\mathrm{AX}=$ Amoxacillin $500 \mathrm{mg} \mathrm{Q8H}$ for 7 days

$\mathrm{AP}=$ Ampicillin $500 \mathrm{mg}$ Q6H for 7 days

$\mathrm{CL}=$ Cloxacillin $500 \mathrm{mg}$ Q6H for 7 days

$0=$ None given

$\mathrm{N}=\mathrm{No}$

$\mathrm{Y}=\mathrm{Yes}$

NA $=$ Not available

$\mathrm{CF}=$ Ciprofloxacin $500 \mathrm{mg} \mathrm{Q} 12 \mathrm{H}$ for 7 days

$\mathrm{KF}=$ Keflex $500 \mathrm{mg}$ Q6H for 7 days

$\mathrm{CX}=$ Cefuroxine $1 \mathrm{~g}$ Q8H Cefotaxine $1 \mathrm{~g} \mathrm{Q} 8 \mathrm{H}$ for 2 days

$\mathrm{GT}=$ Gentamycin $100 \mathrm{mg}$ QD

$\mathrm{DC}=$ Discharged 


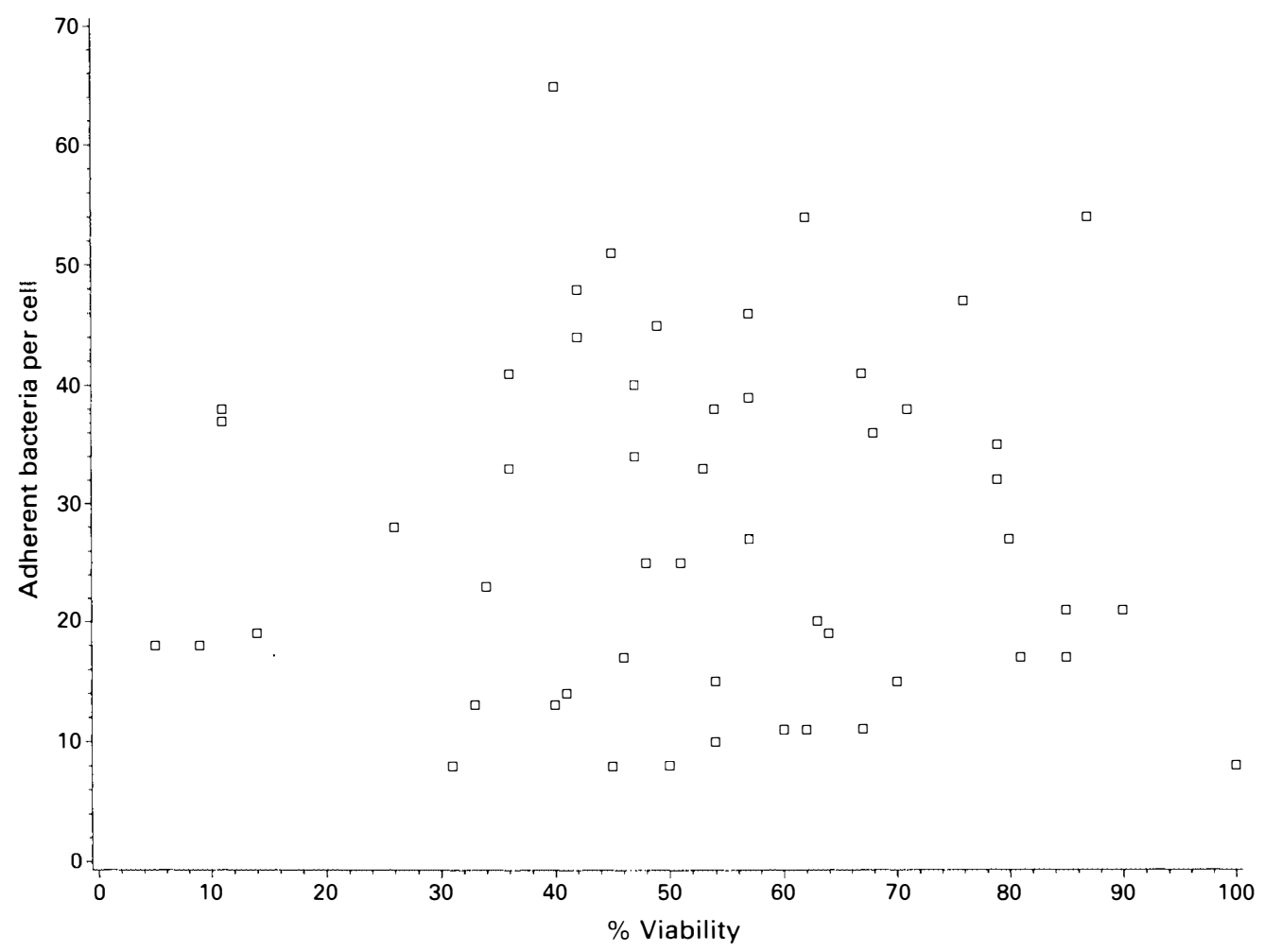

Figure 1 Plot of mean bacterial adhesion counts vs percentage bladder cell viability, showing no direct correlation $(r=-0.01)$.

$55 \pm 23 \%$ asymptomatic) implying that similar damage to the bladder uroepithelium was occurring with and without signs and symptoms of infection.

The white cell counts were calculated as per Stamm, ${ }^{4}$ where a count of less that 10 cells $/ \mathrm{mm}^{3}$ in uncentrifuged urine was regarded as nonpathologic. The results showed a significant increase over controls for leukocyte counts from the SCI patients (16 vs 185 per $1000 \mathrm{~mm}){ }^{3}$

The in vitro studies showed a $28 \%$ drop in cell viability when cells were incubated with $E$. coli (the in vivo drop for $E$. coli infected samples was $52 \%$ ), a $37 \%$ drop for $K$. pneumoniae (58\% in vivo), a $29 \%$ drop for Ps. aeruginosa (64\% in vivo), and $38 \%$ for E. faecalis (59\% in vivo).

\section{Discussion}

The present study confirms and extends our previous findings, ${ }^{1}$ and combined we now have evidence from 18 patients to show that bacterial biofilms could be found on $86 \%$ of bladder cells from 99 SCI patient samples. In addition, the biofilms were found in $95 \%$ of samples taken from antibiotic treated patients. Of these, $52 \%$ of the patients given antibiotics became asymptomatic. The occurrence of $E$. coli, $K$. pneumoniae and $P$ s. aeruginosa was not unexpected, ${ }^{5}$ but the common presence of enterococcus species in the latest study was more in line with our recent experience of outpatients attending a hospital, ${ }^{6}$ and those causing bacteremia in SCI patients. ${ }^{7}$ The present study also showed a higher rate than our previous study $^{1}$ of samples where the urine culture was negative but the uroepithelial cells were covered with adherent bacterial biofilms (58\% vs $16 \%)^{1}$

The comparable numbers of adherent bacteria for patients treated with antibiotics and those untreated demonstrated that the agents used did not eradicate the biofilms. 
In most cases (22 of 33), trimethoprim sulfamethoxazole (co-trimoxazole) was administered. The sample sizes were not large enough to compare this against other agents, but previous human studies have shown that norfloxacin can potentially eradicate infecting organisms from SCI patients, although relapses were common. ${ }^{8}$ In vitro data have demonstrated that another fluoroquinolone, ciprofloxacin, can prevent the development of biofilms and eradicate a large percentage of biofilm organisms. ${ }^{9}$ With the high potency of these agents, it would appear that better management can be achieved if 3 or at most 7 days therapy is used, rather than 14 days, ${ }^{2}$ if the aim is to temporarily clear the organisms from the bladder or impact on symptoms, while minimizing emergence of drug resistant organisms.

The issue of symptomatology is less clear. Unlike the findings, albeit not verified by others, in normal adult females where bacterial adhesion appeared to correlate with symptoms,${ }^{10}$ the adhesion counts for the SCI patients were the same whether or not signs and symptoms of infection presented. This is in agreement with our previous findings for acute, symptomatic UTI in otherwise healthy adult females, where infection arose with only a few adherent bacteria per bladder cell. ${ }^{11}$ If the same number of bacteria were present in both groups, why does one group 'feel' or 'know' it has infection? In order to investigate possible damage to the uroepithelium, we examined the viability of bladder cells from the patients. The findings were quite striking, in that a $33 \%$ loss in viability occurred compared to controls. Half the sloughed cells were dead, although the high adhesion counts were not due to more organisms binding to the dead cells. The loss in viability occurred in symptomatic and asymptomatic patients, illustrating tissue invasion in both groups, and suggesting that other, as yet unidentified, host factors play an important role in causing the onset of signs and symptoms. It would be of interest to carry out cystoscopy investigations in the symptomatic UTI and asymptomatic bacteriuria SCI patients to visibly and by histochemical analyses confirm the existence of inflammation and tissue damage. The high white cell counts in the urines were further testimony to apparent tissue damage. The leukocyte results were even higher than those reported for other SCI patients, ${ }^{12}$ placing the patients at an increased risk of significant morbidity. ${ }^{13}$

The in vitro results also showed a loss in cell viability even within an hour, and suggested that bacteria and/or their byproducts were capable of causing bladder cells to die at a rate faster than by natural causes. The actual products responsible for this cell death were not identified, and although endotoxin may be one possible mediator, ${ }^{14}$ there are likely other factors involved, because Gram positive pathogens also inflicted cell death.

In conclusion, there is evidence to contradict the belief that asymptomatic bacteriuria is of no consequence to the integrity of the urinary tract. ${ }^{15}$ It would appear that the current antibiotic regimens only alter the symptomatology in some patients, but do not eradicate infecting organisms. If, as has been suggested ${ }^{2}$ treatment is to commence without awaiting culture results, highly potent agents, such as the fluoroquinolones, should be considered for 3-7 days duration. If the decision is made not to treat asymptomatic bacteriuria, it should be appreciated that the organisms growing in the bladder are likely conferring damage on the host. The clinical consequences of this damage remain to be determined.

It is almost certain that pathogens in biofilms will reinfect the patient at a later date. At present, there is no alternative method to manage these patients. A previous report of the use of avirulent organisms implanted into the bladder ${ }^{16}$ and several studies using lactobacillus implanted onto the urogenital epithelia ${ }^{17,18}$ suggest that some infections could possibly be prevented by bacterial interference technology, if this is commercialized sometime in the future.

\section{Acknowledgements}

This study was made possible by a grant from the Medical Research Council of Canada. A contribution was made to the cost of the nursing and technical assistance through Parkwood Hospital Foundation and the Miles/URIF pro- 
gram. The cooperation of the patients and staff at Parkwood Hospital is appreciated, as is the assistance of Dr J Denstedt for access to volunteers.

\section{References}

1 Reid G, Charbonneau-Smith R, Lam D, Kang YS, Lacerte M, Hayes KC (1992) Bacterial biofilm formation in the urinary bladder of spinal cord injured patients. Paraplegia 30: 711-717.

2 National Institute of Disability and Rehabilitation Research Consensus Statement (1992) The prevention and management of urinary tract infections among people with spinal cord injuries. J Am Paraplegia Soc 15: $194-204$.

3 Stover SL, Lloyd LK, Waites KB, Jackson AB (1989) Urinary tract infection in spinal cord injury. Arch Phys Med Rehabil 70: 47-54.

4 Stamm WE (1983) Measurement of pyuria and its relation to bacteriuria. Am J Med 75: 53-58.

5 Gilmore DS, Schick DG, Young MN, Montgomerie JZ (1992) Effect of external urinary collection system on colonization and urinary tract infections with Pseudomonas and Klebsiella in men with spinal cord injury. J Am Paraplegia Soc 15: 155-157.

6 Preston CAK, Bruce AW, Reid G (1992) Antibiotic resistance or urinary pathogens isolated from patients attending The Toronto Hospital between 1986 and 1990. J Hosp Infect 22: 129-135.

7 Montgomerie JZ, Chan E, Gilmore DS, Canawati HN, Sapico FL (1991) Low mortality among patients with spinal cord injury and bacteremia. Rev Infect Dis 13: 867-871.

8 Waites KB, Canupp KC, DeVivo MJ (1991) Efficacy and tolerance of norfloxacin in treatment of complicated urinary tract infection in outpatients with neurogenic bladder secondary to spinal cord injury. Urology 38: 589-596.

9 Reid G, Tieszer C, Foerch R, Busscher HJ, Khoury AE, Bruce AW (1993) Adsorption of ciprofloxacin to urinary catheters and effect on subsequent bacterial adhesion and survival. Colloids and Surfaces B: Biointerfaces.

10 Svanborg Eden C, Hanson LA, Jodal U, Lindberg U, Sohl Akerlund A (1976) Variable adherence to normal human urinary-tract epithelial cells of Escherichia coli strains associated with various forms of urinary-tract infection. Lancet (ii): 490-492.

11 Reid G, Brooks HJL (1985) A fluorescent antibody staining technique to detect bacterial adherence to urinary tract epithelial cells. Stain Technol 60: 211-217.

12 Gribble MJ, Puterman ML, McCallum NM (1989) Pyuria: its relationship to bacteriuria in spinal cord injured patients on intermittent catheterization. Arch Phys Med Rehabil 70: 376-379.

13 Menon EB, Tan ES (1992) Pyuria: index of infection in patients with spinal cord injuries. Br J Urol 69: $144-146$.

14 Hurley JC, Louis WJ, Tosolini FA, Carlin JB (1991) Antibiotic-induced release of endotoxin in chronically bacteriuric patients. Antimicrob Agents Chemother 35: 2388-2394.

15 Sotolongo JR Jr, Koleilat N (1990) Significance of asymptomatic bacteriuria in spinal cord injury patients on condom catheter. J Urol 143: 979-980.

16 Hagberg L, Bruce AW, Reid G, Svanborg Eden C, Lincoln K, Lidin-Janson G (1989) Colonization of the urinary tract with live bacteria from the normal fecal and urethral flora in patients with recurrent symptomatic urinary tract infections. In: E H Kass, C Svanborg Eden, editors. Host-parasite Interactions in Urinary Tract Infections. University of Chicago Press: 194-197.

17 Reid G, Bruce AW, McGroarty JA, Cheng K-J, Costerton JW (1990) Is there a role for lactobacilli in prevention of urogenital and intestinal infections? Clin Microbiol Rev 3: 335-344.

18 Bruce AW, Reid G, McGroarty JA, Taylor M, Preston C (1992) Preliminary study on the prevention of recurrent urinary tract infections in ten adult women using intravaginal lactobacilli. Int Urogynecol $J$ 3: $22-25$. 